\title{
Thunderclap-like headache triggered by micturition and angina as an initial manifestation of bladder pheochromocytoma. A case report
}

\section{Cefaleia trovoada-símile desencadeada pela micção e angina como manifestação inicial de feocromocitoma de bexiga. Um relato de caso}

You Jin Han', So Young Ock', Eun Jung Kim', Ho Sik Shin", Yeon Soon Jung'", Hark Rim"

Department of Internal Medicine, Kosin University College of Medicine, Busan, Korea

'MD. Resident Physician, Department of Internal Medicine, Kosin University College of Medicine, Busan, Korea.

"MD. Assistant Professor, Department of Internal Medicine, Kosin University College of Medicine, Busan, Korea

'"MD, PhD. Associate Professor, Department of Internal Medicine, Kosin University College of Medicine, Busan, Korea

"MD, PhD. Professor, Department of Internal Medicine, Kosin University College of Medicine, Busan, Korea

\section{KEY WORDS:}

Pheochromocytoma.

Headache disorders, primary

Micturition.

Angina pectoris.

Catecholamines.

\section{PALAVRAS-CHAVE:}

Feocromocitoma.

Transtornos da cefaleia primários.

Micção.

Angina pectoris.

Catecolaminas.

\section{ABSTRACT}

CONTEXT: Pheochromocytoma is a catecholamine-producing tumor characterized by hypertension, headache, tachycardia, excessive diaphoresis and angina. The thunderclap headache is so named because the pain strikes suddenly and severely. Although the symptoms of bladder pheochromocytoma are rather evident, the diagnosis of this rare neuroendocrine tumor can be missed.

CASE REPORT: This study reports the case of a woman diagnosed with bladder pheochromocytoma who experienced thunderclap headache triggered by micturition and angina as an initial manifestation.

CONCLUSION: This case study suggests that thunderclap headache and angina occurring concurrently with sudden blood pressure elevation during or immediately after micturition are important diagnostic clues for bladder pheochromocytoma.

\section{RESUMO}

CONTEXTO: Feocromocitoma é um tumor produtor de catecolaminas, caracterizado por hipertensão, cefaleia, taquicardia, sudorese excessiva e angina. A dor de cabeça trovão é assim chamada porque a dor ataca de repente e intensamente. Embora os sintomas de feocromocitoma de bexiga sejam bastante evidentes, o diagnóstico deste tumor neuroendócrino raro pode ser perdido.

RELATO DE CASO: Este estudo relata o caso de uma mulher diagnosticada com feocromocitoma na bexiga que sentiu a dor de cabeça trovão, desencadeada pela micção e angina como manifestação inicial. CONCLUSÃO: Este estudo de caso sugere que a dor de cabeça trovão e angina ocorrendo simultaneamente com a elevação da pressão de sangue repentina durante ou imediatamente após a micção são dicas importantes de diagnósticos de feocromocitoma na bexiga. 


\section{INTRODUCTION}

Pheochromocytoma, which is a catecholamine-producing tumor that causes secondary hypertension, arises from any location in which the chromaffin cells of the sympathetic nervous system are present. ${ }^{1}$ In adults, approximately $90 \%$ of pheochromocytomas arise within the adrenal medulla and about $10 \%$ of extra-adrenal pheochromocytomas arise from the chromaffin cells of the paraganglionic system in the bladder, cranium and abdomen. ${ }^{2}$ Bladder pheochromocytoma is an especially rare neuroendocrine tumor that accounts for less than $1 \%$ of all pheochromocytomas and less than $0.06 \%$ of all bladder tumors. ${ }^{3}$

In most cases, history-taking is the most important tool for preoperatively diagnosing pheochromocytomas that primarily originate from the bladder. An elevated 24-h urinary excretion level of epinephrine and norepinephrine with their metabolites is the confirmatory diagnostic tool. ${ }^{4}$ The typical clinical presentation of bladder pheochromocytoma is macroscopic hematuria, paroxysmal or persistent hypertension, tachycardia, angina, excessive diaphoresis, facial pallor and weakness, and approximately $50 \%$ of the patients experience thunderclap headache (TCH) after micturition.,

We report the case of a patient diagnosed with bladder pheochromocytoma who had recurrent $\mathrm{TCH}$ after micturition and angina.

\section{CASE REPORT}

A 61-year-old woman was admitted at this time with recurrent headaches after micturition and angina. She had experienced syncope during micturition 15 years prior to admission, and she had undergone coronary angiography and ballooning for chest pain, with angina diagnosed three years later (12 years prior to admission). Two years later, in 2002, the patient was found to have a bladder tumor. Imaging was the only form of followup performed for the tumor, which remained the same size until 2007. For seven years prior to admission, she experienced recurrent $\mathrm{TCH}$ with hypertension immediately after micturition or during micturition, and treatment with antihypertensive medication had not resulted in improvement. There was no known family history of pheochromocytoma.

The findings from physical examination at the present admission, including funduscopic findings, were unremarkable. Her blood pressure was 120/90 $\mathrm{mmHg}$ upon admission but became elevated to $230 / 110 \mathrm{mmHg}$ after micturition. An electrocardiogram revealed a 2-mm elevation on lead V2-3 and T-wave inversion on V2-6 (data not shown). Coronary angiography did not reveal any significant stenosis but a 30\% tubular eccentric narrowing feature was found in the proximal left anterior descending artery, which implied minimal coronary artery disease.
An echocardiogram showed that the ejection fraction of the left ventricle was $72 \%$ with intact wall motion. We suspected bladder pheochromocytoma on the basis of her history and symptoms, such as headache related to micturition and angina.

Her 24-h urinary biochemical analysis showed the following findings: vanillylmandelic acid (VMA), $5.93 \mathrm{mg} /$ day (normal range: 2-8 $\mathrm{mg} /$ day); metanephrine, $473 \mu \mathrm{g} /$ day (normal range: 0-300 $\mu \mathrm{g} /$ day); normetanephrine, $1508 \mu \mathrm{g} /$ day (normal range: 0-600 $\mu \mathrm{g} /$ day); epinephrine $10.4 \mu \mathrm{g} /$ day (normal range: 0-20 $\mu \mathrm{g} /$ day); and norepinephrine $171.3 \mu \mathrm{g} /$ day (normal range: 15-80 $\mu \mathrm{g} /$ day). The blood sampling analysis showed the following results: dopamine, $0.042 \mathrm{ng} / \mathrm{ml}$ (normal range: $0-0.2 \mathrm{ng} / \mathrm{ml}$ ); epinephrine, $0.153 \mathrm{ng} / \mathrm{ml}$ (normal range: $0-0.3 \mathrm{ng} / \mathrm{ml}$ ); norepinephrine, $0.5 \mathrm{ng} / \mathrm{ml}$ (normal range: $0-0.8 \mathrm{ng} / \mathrm{ml}$ ); renin activity, $0.32 \mathrm{ng} / \mathrm{ml} / \mathrm{h}$ (normal range: $0.1-0.0-6 \mathrm{ng} / \mathrm{ml} / \mathrm{h}$ ); aldosterone, $61.5 \mathrm{pg} / \mathrm{ml}$ (normal range: 40-310 pg/ml); adrenocorticotropic hormone (ACTH), $46.3 \mathrm{pg} / \mathrm{ml}$ (normal range: 0-80 pg/ml); cortisol, $11.30 \mathrm{ug} / \mathrm{dl}$ (normal range: 4.30-22.40 ug/dl); fasting glucose, $103 \mathrm{mg} / \mathrm{dl}$ (normal range: $70-124 \mathrm{mg} / \mathrm{dl}$ ); white blood cell (WBC) count, 6,200; hemoglobin (Hb) 12.2 (normal range: 12.0-16.7 g/dl); and platelets 189,000 (normal range: 144,000-351,000/uL). A contrast-enhanced computed tomography (CT) scan of her abdomen and pelvis revealed a well-enhanced, solid mass of dimensions $3 \times 3.2 \mathrm{~cm}$, on the left lateral wall of the bladder (Figure 1). When the CT was performed, the patient's blood pressure (BP) level was normal. Single-photon emission computed

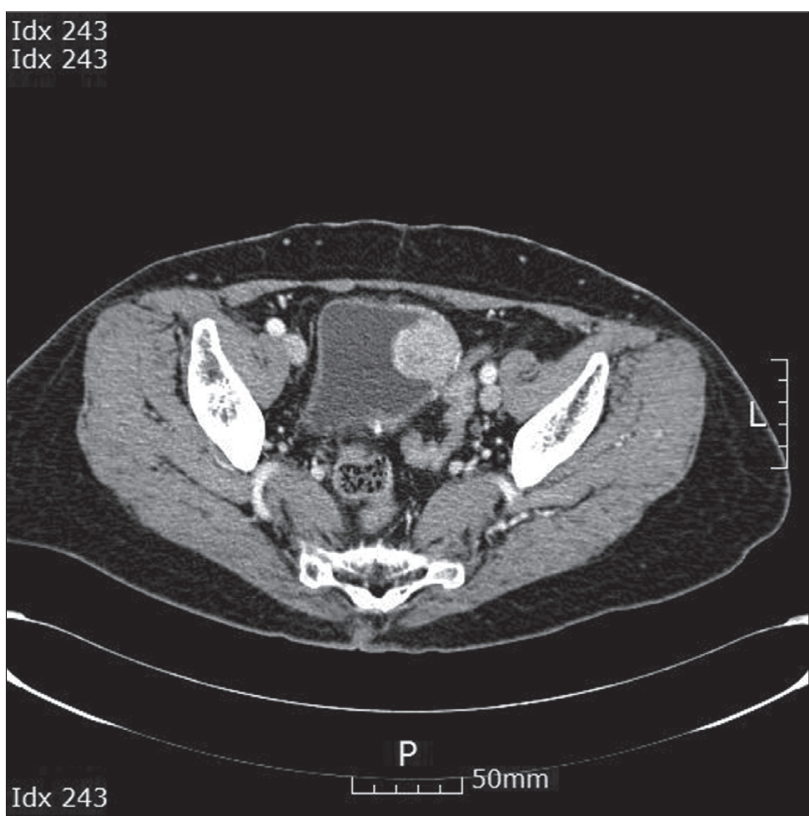

Figure 1. Abdominal computed tomography showing an intraluminal polypoid mass of approximately $3 \times 3.2 \mathrm{~cm}$ in size with heterogeneous enhancement on the left lateral wall of the urinary bladder. 
tomography (SPECT) using I-131 metaiodobenzylguanidine (I-131 MIBG) only showed increased uptake in the urinary bladder on its left lateral wall (Figure 2). We diagnosed this case as bladder pheochromocytoma and recommended surgery.

After preoperative treatment with an $\alpha$-blocker (doxazosin) for two weeks, the patient underwent partial cystectomy under general anesthesia. Immunohistochemical analyses revealed that the tumor cells were positive for CD56, chromogranin and synaptophysin. No remnant tumor was detected on follow-up cystoscopy after surgery, and the patient's symptoms subsided. She no longer experienced TCH triggered by micturition and angina.

Histological examination confirmed the diagnosis of bladder pheochromocytoma with morphological features that indicated benign behavior. Macroscopically, the surgical specimen measured $3 \times 3.2 \mathrm{~cm}$ in size and the lesion appeared yellow/brown in color and measured $3 \mathrm{~cm}$ at the cut surface (Figure 3). Microscopically, the tumor was associated with the muscular bladder wall, whereas the bladder urothelium and the subepithelial stroma were preserved (Figure 4). No evidence of vascular/capsular invasion, necrosis, mitosis or hemorrhage was found. All of the morphological features included in the Pheochromocytoma of the Adrenal gland Scaled Score (PASS) were evaluated, resulting in a PASS score of $<2 / 20$ (tumor with benign behavior). ${ }^{3}$ Immunohistochemical analysis demonstrated positivity for chromogranin A, S-100 and synaptophysin.

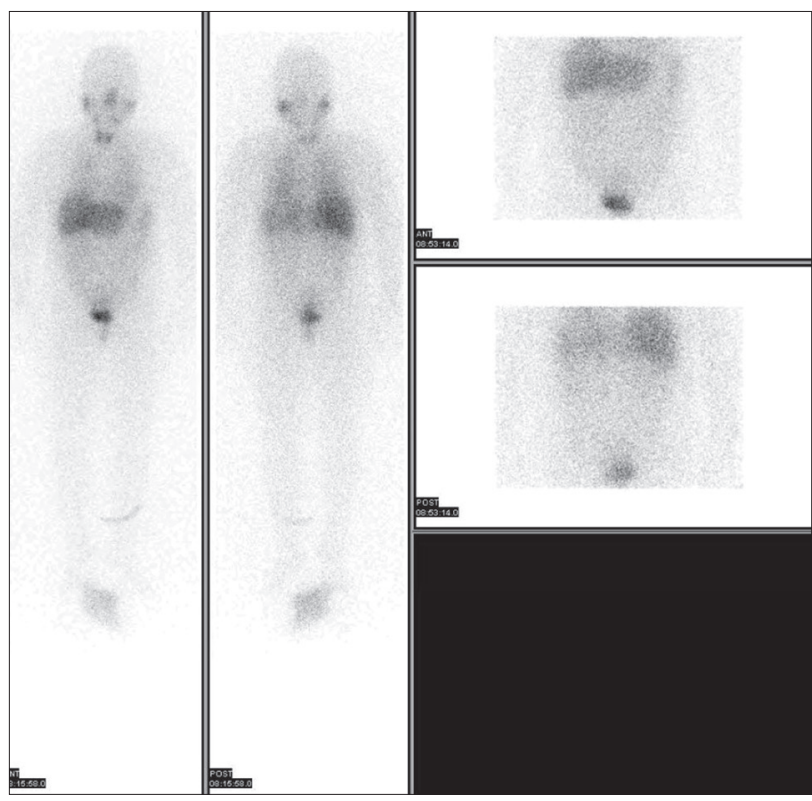

Figure 2. ${ }^{131} \mathrm{I}-\mathrm{MIBG}$ (metaiodobenzylguanidine) scan showing partial uptake on the left side of the urinary bladder, which is consistent with pheochromocytoma.

\section{DISCUSSION}

Paragangliomas are rare neuroendocrine neoplasms that develop from the germinal cells of the neural crest and usually involve the adrenal glands. Bladder pheochromocytoma is a particularly unusual form of paraganglioma that represents less than $1 \%$ of all pheochromocytomas. ${ }^{7}$ A systematic survey of indexed articles using the terms "pheochromocytoma" and "thunderclap headache" in Medline and Cochrane Library databases and $\mathrm{MeSH}$ (Medical Subject Headings) revealed that only five articles have been published on this topic to this date. All of these papers were found in Medline, Embase, Lilacs and the Cochrane Library (Table 1). ${ }^{1-21}$

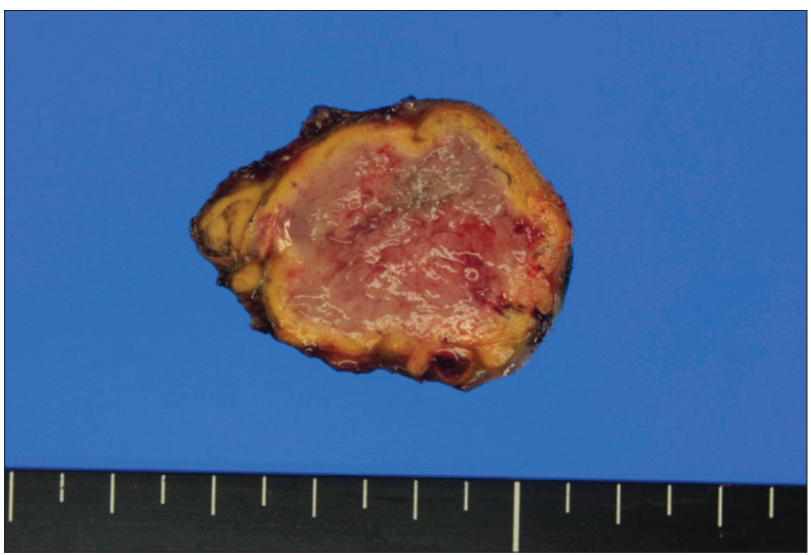

Figure 3. Macroscopically, the pheochromocytoma was a $3 \times 3.2-\mathrm{cm}$ sized mass abutting from the left wall of the urinary bladder.

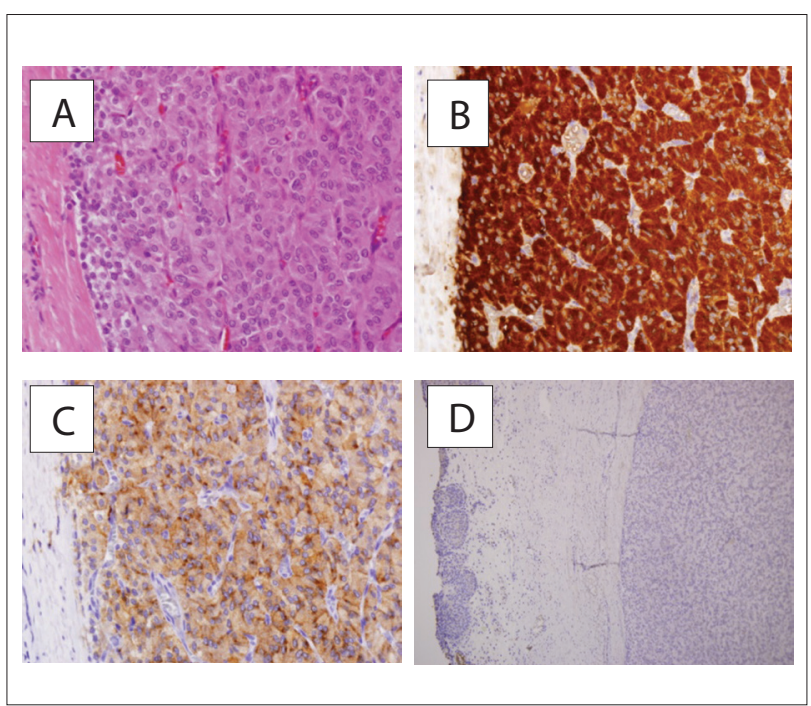

Figure 4. Immunohistochemical analyses revealing that the tumor cells were positive for chromogranin A, S-100 and synaptophysin. (A) Hematoxylin and eosin staining $(\times 400)$. (B) Chromogranin staining $(\times 100)$. (C) S-100 staining $(\times 40)$. (D) Synaptophysin staining $(\times 400)$. 
Table 1. Results from our reviews of medical databases using descriptors for the main clinical findings observed in our patient: February 1, 2013

\begin{tabular}{|c|c|c|}
\hline Database & Search strategy & Results \\
\hline $\begin{array}{l}\text { Medline } \\
\text { (via PubMed) }\end{array}$ & $\begin{array}{l}\text { "Pheochromocytoma" AND } \\
\text { "Thunderclap headache" }\end{array}$ & $\begin{array}{l}6 \text { case reports } 5,6,9,10,15,18 \\
15 \text { reviews of the } \\
\text { literature }^{1-4,7,8,11-14,16,17,19-21}\end{array}$ \\
\hline Embase & $\begin{array}{l}\text { "Pheochromocytoma" AND } \\
\text { "Thunderclap headache" }\end{array}$ & $\begin{array}{l}6 \text { case reports }^{5,6,9,10,15,18} \\
15 \text { reviews of the } \\
\text { literature }\end{array}$ \\
\hline $\begin{array}{l}\text { Lilacs } \\
\text { (via Bireme) }\end{array}$ & $\begin{array}{l}\text { "Pheochromocytoma" AND } \\
\text { "Thunderclap headache" }\end{array}$ & $\begin{array}{l}6 \text { case reports } 5,6,9,10,15,18 \\
15 \text { reviews of the } \\
\text { literature }^{1-4,7,8,11-14,16,17,19-21}\end{array}$ \\
\hline
\end{tabular}

The clinical features of bladder pheochromocytoma are various and include hematuria and hypertensive crisis together with headache, angina, palpitation, hot flashes and sweating. These crises are typically induced by micturition or overdistension of the bladder, which leads to systemic release of catecholamines. However, not all bladder pheochromocytomas result in this syndrome and some show no hormonal activity. Signs of hormonal activity are seen in $83 \%$ of bladder pheochromocytomas in the literature. ${ }^{8}$ In these cases, the diagnosis can be completely incidental. Therefore, detecting the disease requires a high degree of clinical suspicion based on the patient's symptoms, owing to both the rarity of this lesion and the variety of its clinical features. ${ }^{9}$

$\mathrm{TCH}$ is a hyper-acute, severe headache that reaches maximum intensity at onset. The term TCH was first used to describe the headache caused by unruptured intracerebral aneurysms, and patients frequently describe this type of headache as the worst headache of their lives. ${ }^{10}$

This sudden, severe headache peaks within $60 \mathrm{~s}$ and usually fades over several hours. ${ }^{11}$ TCH may be an indication of a medical emergency, such as aneurysmal subarachnoid hemorrhage, pituitary apoplexy, carotid or vertebral artery dissection, acute hypertensive crisis and cerebral venous sinus thrombosis, which often leads to death or severe disability. ${ }^{12}$ Therefore, immediate medical attention is needed for any headache that comes on suddenly and severely. In our case, the patient's usual systolic BP and diastolic BP were $100-110 \mathrm{mmHg} / 60-70 \mathrm{mmHg}$, but the systolic BP increased to an average of $180-200 \mathrm{mmHg}$ and the diastolic $\mathrm{BP}$ to $100-120 \mathrm{mmHg}$ after micturition. The underlying cause of recurrent $\mathrm{TCH}$ with these hypertensive crises was bladder pheochromocytoma, which can lead to a potentially lethal condition when unrecognized.

The diagnosis of pheochromocytoma is supported by measurements of catecholamines and their metabolites metanephrine and normetanephrine, in plasma and 24-h urine samples. $^{7}$ In a study conducted on patients with extra-adrenal pheochromocytomas, the urinary metanephrine rate was high in $88 \%$ of the cases. ${ }^{13}$ In our case, the level of 24 -h urine metanephrine became elevated to $473 \mu \mathrm{g} /$ day. After biochemical tests, imaging techniques such as CT or magnetic resonance imaging should be performed to locate the neoplasm. The diagnosis can be enhanced by iodine-MIBG scanning, which has a sensitivity of $78 \%$ for adrenal pheochromocytomas and $67-89 \%$ for extra-adrenal locations. ${ }^{8}$

We used contrast-enhanced CT scans and iodine-MIBG scanning to diagnose and determine the location of the tumor. To date, no definitive biochemical or histological markers have been defined for distinguishing benign from malignant tumors. The only definitive proof of malignancy is the presence of metastasis to other organs. ${ }^{14}$ No standardized histological features or any scoring system to distinguish benign from malignant bladder pheochromocytomas have yet been reported in the literature.

The PASS system, which is usually used to study adrenal gland pheochromocytomas, ${ }^{3}$ was applied to determine whether the tumor had benign or aggressive behavior in the present case. Application of these criteria to a larger series of bladder pheochromocytomas may help to evaluate the presence of malignant bladder pheochromocytoma. The PASS system can be applied to bladder pheochromocytomas as well as to adrenal gland pheochromocytomas.

This case showed a PASS score of $<2 / 20$, thus indicating benign tumor behavior. Microscopically, bladder pheochromocytomas produce submucosal or intramucosal masses; furthermore, they are covered by intact epithelium and are characterized by the presence of nests ("Zellballen") or cords of cells delimited by fibrovascular connective tissue. The majority of the cells are medium-to-large and polyhedral, and have eosinophilic cytoplasm and ovoid nuclei. The unclear chromatin is dispersed and one or more nucleoli are generally present. Large bizarre nuclei may be seen. ${ }^{15}$ In our case, these cells involved the true muscle, submucosa and mucosal layer with positivity for chromogranin A, S-100 and synaptophysin, and were confirmed as bladder pheochromocytoma.

Bladder pheochromocytoma is an extremely rare disease. ${ }^{16}$ Because of its rarity, diagnosing bladder pheochromocytoma preoperatively may be difficult and delayed, in spite of the characteristic diagnostic clues such as paroxysmal hypertension and headache immediately after micturition. ${ }^{17}$ Diagnostic delays as long as several years from the onset of symptoms have been reported, which can probably be attributed to the rarity of the tumor. ${ }^{18}$ Although laboratory and radiological investigations are informative and necessary for diagnosing bladder pheochromocytoma, a high degree of suspicion based on a detailed history and physical findings is very important. Such suspicions facilitate early diagnosis and treatment of the tumor, which leads to a good outcome. ${ }^{18}$

In our case, a detailed history that included headache-provoking factors and detection of the transient hypertension and 
angina induced by micturition provided early diagnostic clues for this rare disease. Through recognizing the relationship between headache and micturition, we were alerted to the possibility of bladder pheochromocytoma in this case. Common presenting features of bladder pheochromocytoma include symptoms of painless hematuria, diaphoresis, hypertension, angina, headache, palpitation and fainting after micturition, caused by catecholamine release. ${ }^{16}$

In this case, blood pressure elevation was apparent following micturition and activities with the capability of increasing the pressure inside the abdomen, which would thus push down on the bladder. Imaging studies are useful for planning definitive treatment because they can determine both the tumor location and whether multiple sites of involvement or metastases exist. ${ }^{17}$

In our case, the diagnosis was established by finding increased levels of catecholamine metabolites in the urine and CT imaging after clinical suspicion. The optimal treatment for pheochromocytoma is prompt surgical excision, because these patients are at significant risk of lethal complications such as hypertensive crisis. ${ }^{17}$ Patient preparation is an essential step and includes preoperative treatment with $\alpha$ - and $\beta$-blocking agents. ${ }^{19}$ Open surgery to perform partial cystectomy is recommended because of the multilayer involvement of the bladder wall. Radical cystectomy with pelvic lymphadenectomy is recommended if metastasis is definitely present. ${ }^{8}$ Radiotherapy and chemotherapy have limited effectiveness.

Extra-adrenal pheochromocytomas are more likely to recur and metastasize than their adrenal counterparts, thus making long-term follow-up with annual determinations of catecholamine production essential because it is not histologically feasible to differentiate benign from malignant pheochromocytomas. ${ }^{17}$

Long-term follow-up with regular biological and clinical examinations is also necessary in order to detect recurrence or metastasis. Although no standard criteria for malignancy exist from a histological perspective, appearance of a metastasis is a sign of malignancy. ${ }^{20}$

Of the 170 cases of bladder pheochromocytoma that have been reported so far, only 17 well-documented cases were malignant. $^{21}$ Thus, the prognosis for bladder pheochromocytoma remains favorable.

\section{CONCLUSION}

In summary, this case serves as a reminder of the importance of thorough history-taking and clinical examination in making diagnoses. Nephrologists, endocrinologists, cardiologists and urologists should work together to minimize the risk of misdiagnosis. This case study suggests that $\mathrm{TCH}$ and angina occurring concurrently with sudden blood pressure elevation during or immediately after micturition are important diagnostic clues for bladder pheochromocytoma.

\section{REFERENCES}

1. Whalen RK, Althausen AF, Daniels GH. Extra-adrenal pheochromocytoma. J Urol. 1992;147(1):1-10.

2. Gifford RW Jr, Manger WM, Bravo EL. Pheochromocytoma. Endocrinol Metab Clin North Am. 1994;23(2):387-404

3. Thompson LD. Pheochromocytoma of the Adrenal gland Scaled Score (PASS) to separate benign from malignant neoplasm: a clinicopathologic and immunophenotypic study of 100 cases. Am J Surg Pathol. 2002;26(5):551-66.

4. Pacak K, Linehan WM, Eisenhofer G, Walther MM, Goldstein DS Recent advances in genetics, diagnosis, localization, and treatment of pheochromocytoma. Ann Intern Med. 2001;134(4):315-29.

5. Bourne RB, Beltaos E. Pheochromocytoma of the bladder: case report and summary of literature. J Urol. 1967;98(3):361-4

6. Fraley SE, Smith CL. Unusual location of pheochromocytoma in the urinary bladder. J Urol. 1959;81(1):130-2.

7. Kappers $\mathbf{M H}$, van den Meiracker AH, Alwani RA, Kats E, Baggen MG. Paraganglioma of the urinary bladder. Neth J Med. 2008;66(4):163-5.

8. Tazi MF, Ahallal $Y$, Tazi $E$, et al. Pheochromocytoma of the urinary bladder: a case report. Cases J. 2009;2:8585.

9. Seki N,MukaiS, Gamachi A, etal.A case ofbladder pheochromocytoma. Urol Int. 2001;66(1):57-60.

10. Day JW, Raskin NH. Thunderclap headache: symptom of unruptured cerebral aneurysm. Lancet. 1986;2(8518):1247-8.

11. Schwedt TJ. Clinical spectrum of thunderclap headache. Expert Rev Neurother. 2007;7(9):1135-44

12. Schwedt TJ, Matharu MS, Dodick DW. Thunderclap headache. Lancet Neurol. 2006;5(7):621-31

13. Goldfarb DA, Novick AC, Bravo EL, et al. Experience with extra-adrenal pheochromocytoma. J Urol. 1989;142(4):931-6.

14. Huang KH, Ching SD, Chen SC, et al. Clinical and pathological data of 10 malignant pheochromocytomas: long-term follow up in a single institute. Int J Urol. 2007;14(3):181-5.

15. Sung KT, Lee SK, Yoon JB. Pheochromocytoma of the urinary bladder. Korean J Urol. 1991;32(5):829-35. Available from: http://koreamed. org/SearchBasic.php?RID=1020KJU\%2F1991.32.5.829\&DT=1\&QY=\% 22Korean+J+Urol\%22+\%5BJTI\%5D++AND+32+\%5BVO\%5D+AND+ 5+\%5BISSU\%5D. Accessed in 2013 (Oct 25).

16. Celiktas M, Okur N, Aikimbaev KS, et al. Bladder pheochromocytoma encountered on sonography. Australas Radiol. 2004; 48(3):398-400

17. Fujishima S, Abe I, Kaseda S, et al. Ambulatory blood pressure monitoring in diagnosing a pheochromocytoma of the urinary bladder. A case report. Angiology. 1997;48(7):655-8.

18. Doran F, Varinli S, Bayazit Y, Bal N, Ozdemir S. Pheochromocytoma of the urinary bladder. APMIS. 2002;110(10):733-6.

19. Ram CV, Engelman K. Pheochromocytoma--recognition and management. Curr Probl Cardiol. 1979;4(1):1-37. 
20. Attyaoui F, Nouira Y, Kbaier I, Ben Younes A, Horchani A. Le phéochromocytome vésical [Bladder pheochromocytoma]. Prog Urole. 2000;10(1):95-8.

21. Michel F, Gattegno B, Sicard JF, Roland J, Thibault P. A propos d'une observation de phéochromocytome vésical malin: conduite diagnostique et thérapeutique. Ann Urol 1990;24(5):396-9. Available from: http://cat.inist fr/?aModele=afficheN\&cpsidt=19306983. Accessed in 2013 (Oct 25).

Sources of funding: None

Conflict of interest: None

Date of first submission: March 13,2013

Last received: November 6, 2013

Accepted: November 22, 2013

Address for correspondence:

Ho Sik Shin, MD

Department of Internal Medicine

Kosin University College of Medicine, 262

Gamcheon-ro, Seo-gu

Busan, 602-702

Korea

Tel. +82-51-990-6108

Fax. +82-51-248-5686

E-mail: danieljoseph@hanmail.net 